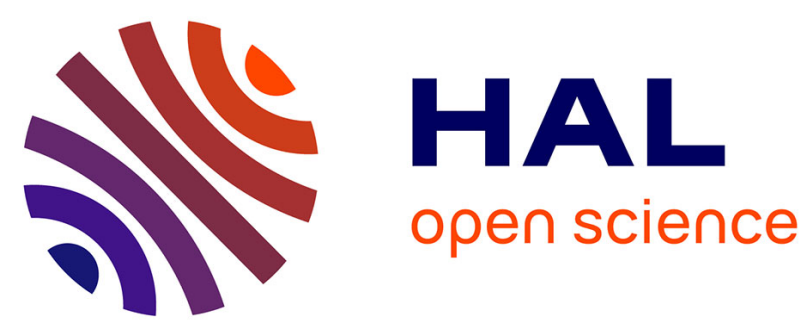

\title{
Large NS convergence at the northern edge of the Tibetan plateau? New Early Cretaceous paleomagnetic data from Hexi Corridor, NW China.
}

\author{
Yan Chen, Hanning Wu, Vincent Courtillot, Stuart A. Gilder
}

\section{To cite this version:}

Yan Chen, Hanning Wu, Vincent Courtillot, Stuart A. Gilder. Large NS convergence at the northern edge of the Tibetan plateau? New Early Cretaceous paleomagnetic data from Hexi Corridor, NW China.. Earth and Planetary Science Letters, 2002, 201, pp.293-307. 10.1016/S0012-821X(02)007227. hal-00076857

\section{HAL Id: hal-00076857 \\ https://hal-insu.archives-ouvertes.fr/hal-00076857}

Submitted on 25 Jun 2013

HAL is a multi-disciplinary open access archive for the deposit and dissemination of scientific research documents, whether they are published or not. The documents may come from teaching and research institutions in France or abroad, or from public or private research centers.
L'archive ouverte pluridisciplinaire HAL, est destinée au dépôt et à la diffusion de documents scientifiques de niveau recherche, publiés ou non, émanant des établissements d'enseignement et de recherche français ou étrangers, des laboratoires publics ou privés. 


\title{
Large $\mathbf{N}-\mathrm{S}$ convergence at the northern edge of the Tibetan plateau? New Early Cretaceous paleomagnetic data from Hexi Corridor, NW China
}

- $\quad$ Yan Chen $^{\mathrm{a}}$

- Hanning $\mathrm{Wu}^{\mathrm{b}}$

- Vincent Courtillot ${ }^{\mathrm{cd}}$

- Stuart Gilder ${ }^{\mathrm{c}}$

- $\quad{ }^{a}$ Département des Sciences de la Terre, ISTO, Université d'Orléans, 45067 Orléans Cedex 2, France

- $\quad{ }^{\mathrm{b}}$ Department of Geology, Northwest University, Xian 710069, PR China

- ${ }^{\mathrm{c}}$ Laboratoire du Paléomagnétisme, Institut de Physique du Globe de Paris, 75252 Paris Cedex 05, France

- ${ }^{\mathrm{d}}$ Division of Geological and Planetary Sciences, Caltech, Pasadena, CA 91125, USA

\begin{abstract}
Nine Early Cretaceous paleomagnetic sites have been collected in the Yumen area of the Hexi Corridor (NW China). Magnetic directions isolated at lower temperatures fail the fold test, and lie close to the geocentric axial dipole field direction before tilt correction. High temperature components are carried by magnetite and/or hematite, all with normal polarity, and pass the fold test. The average paleomagnetic pole from the nine sites is at $\lambda=75.5^{\circ} \mathrm{N}$, $\varphi=169.9^{\circ} \mathrm{E}\left(A_{95}=7.7^{\circ}\right)$. These results are consistent with those from other areas of the North China block (NCB), but significantly different from those from the Qaidam Basin on the southern side of the Qilian Mountains. They suggest that: (1) the Yumen region behaved as a rigid part of the NCB since at least the Early Cretaceous; (2) $740 \pm 500 \mathrm{~km}$ of north-south directed convergence has taken place between the NCB and Qaidam, within the Qilian Mountains and (3) extrusion of Qaidam was accompanied by a $23 \pm 5^{\circ}$ relative rotation with respect to North China. This is larger than implied by the maximum left lateral slip on the Altyn Tagh fault system. The same data imply some $1000 \pm 800 \mathrm{~km}$ of Cenozoic motion between the Tarim and NCB blocks, which were so far believed to have formed a rigid entity since at least the Jurassic. One interpretation could be that all Tarim and Qaidam Cretaceous paleomagnetic samples from red beds, but not those from Yumen and the NCB, suffered significant inclination shallowing, as observed in Cenozoic red beds from Central Asia. So far, we do not find support for this possibility. Possible tectonic interpretations include: (1) the existence of a large, as yet uncharted, tectonic discontinuity between Tarim and the NCB in the vicinity of the desert corridor near $95-100^{\circ} \mathrm{E}$ longitude; (2) the occurrence of significant deformation within southwestern Tarim, to the north of Yingjisha where paleomagnetic sites were obtained, or (3) persistent clockwise rotation of Tarim with respect to the $\mathrm{NCB}$, for at least $20 \mathrm{Ma}$, at the rate found for current block kinematics.
\end{abstract}

\section{Keywords}

- paleomagnetism;

- North China platform;

- Tarim Basin;

- plate convergence;

- Qilian Mountains 


\section{Introduction}

In the last two decades, a large number of field and laboratory studies have considerably expanded our knowledge of the successive phases of accretion and deformation of the Asian continent, both prior to and following its collision with India. Paleomagnetic studies have contributed constraints on the paleogeographic position and amount of deformation of several of the larger blocks that comprise the Asian mosaic. The first data, gathered two decades ago, started with Cretaceous and Eocene rocks in southern Tibet, not far from Lhasa, and then expanded to all of Tibet, including the Qiangtang, Kunlun and finally Qaidam (Fig. 1). In parallel, data were acquired from the apparently more rigid blocks of Tarim and Junggar to the north, and North and South China to the east. This has allowed a number of paleogeographic syntheses to be proposed (e.g. [1] for the Cretaceous). 

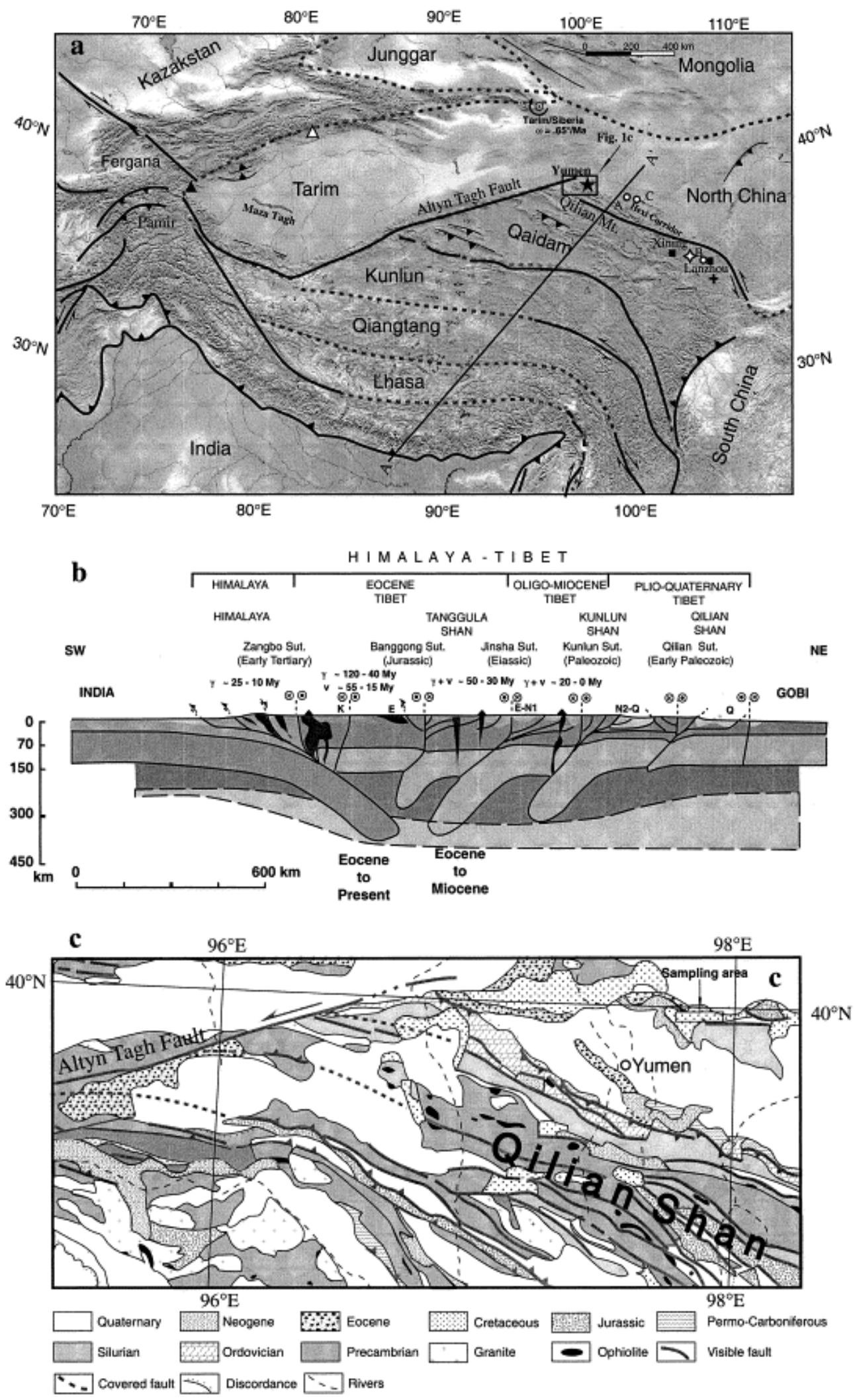

Fig. 1. (a) Topographic map, and (b) tectonic cross section from India to the Gobi Desert (from [26]). The sampling areas are shown by a star for Yumen, a diamond and a cross for the Xining-Lanzhou Basin, a solid (open) triangle for the Tarim Basin ([9], [50], [8] and [52], respectively); A, B and C are for the Sunan, Lanzhou and Zhangye sites of Frost et al. [27]. (c) Simplified geological map of the sampling area [41]. 
Attention was first focused on relative paleolatitude differences between blocks, in general interpreted as indications of north-south convergence, believed to be a direct consequence of the collision. Little motion was found between the apparently rigid blocks of South China (SCB), North China (NCB, including Mongolia) and Siberia since at least Cretaceous time (e.g. [2], [3], [4], [5], [6] and [7]), whereas large northward movement apparently affected blocks to the west of $\sim 100^{\circ} \mathrm{E}$ longitude, i.e. Tibetan blocks, Tarim and Junggar [8] and [9]. This contrasting behavior on either side of $\sim 100^{\circ} \mathrm{E}$ longitude was emphasized early on by Enkin et al. ([4]; see also [9]).

Attention was also focused on rigid versus non-rigid behavior, when the block was large enough, as enough widely separated sites became available. The same papers referenced above attest to the non-rigid deformation of Tibetan blocks, notably the Lhasa and Qiangtang blocks [10], whereas the NCB [11], [12] and [13] and the SCB [7] and [13] were found to have behaved as rigid entities (within paleomagnetic uncertainties) since the Cretaceous. Part of the pre-Cretaceous SCB was non-rigid, as it was deformed during the NCB-SCB collision when Dabie Shan acted as a rigid indentor and punctured it [14]. Analysis of declinations, hence rotations about locally vertical axes, was an important part of these studies.

More recently, attention has focused on ongoing deformation at the northern boundaries of Tibet, i.e. around the Qaidam block [15], [16], [17], [18] and [19], which is separated from Tarim to the northwest by the Altyn Tagh, one of the largest strike-slip fault systems in the world [20] and [21], and from North China to the northeast by the Qilian Shan [17], [22] and [23]. This interest has resulted in new models of northward growth and propagation of the Tibetan plateau since the onset of the collision [24], [25] and [26].

Paleomagnetic constraints from the same areas have become concurrently available (Fig. 1): Frost et al. [27] for either side of the Qilian Shan and Haiyuan fault, Halim et al. [9] for the Qaidam block near Lanzhou in the eastern Nan Shan-Qilian Shan range, Cogné et al. [6] more to the west in the eastern Kunlun ranges, Gilder et al. [28], Dupont-Nivet et al. [29] and Chen et al. [30] for the Qaidam Basin, near and to the south of the Altyn Tagh fault. Halim et al. [9] and Cogné et al. [6] concluded that the Qaidam, Tarim, Kunlun and Junggar had been assembled roughly in their present respective positions in the Cretaceous, but that there was a large discrepancy with respect to the Siberia, Mongolia, NCB, SCB assemblage amounting to a possible NS convergence of $\sim 800 \pm 500 \mathrm{~km}$ between the two ensembles. This problem had emerged from the earlier studies of Chen et al. [10], Frost et al. [27] and Gilder et al. [31]. But given the site locations, the convergence could only vaguely be assigned to any part of the crust between Qaidam and Siberia. And the idea of some major yet so far unobserved tectonic transition zone either in the Qilian Shan, Tarim, Tian Shan, Mongol-Okhotsk or Sayan Tuva ranges was not particularly palatable to geologists, given the lack of field evidence.

Another growing problem has been increasing evidence for anomalously low inclinations, particularly in Paleogene and, most of all, in Neogene rocks in central and eastern Asia (see [6], [28], [31], [32], [33] and [34]). Remagnetization, overlap of components (e.g. [35]), nondipole field geometry (e.g. [36]), error in reference apparent polar wander path (APWP) for Siberia (e.g. [6]), age errors and sedimentological problems (e.g. [28], [37] and [38]) have been invoked to account for these observations. 
In order to provide further constraints on this ongoing discussion, we have undertaken paleomagnetic sampling of Early Cretaceous rocks in the Yumen area of the Hexi corridor, in the Gansu province of Northwestern China (Fig. 1). We conclude that our study apparently provides a primary paleomagnetic direction and pole for Yumen, which turns out to be part of the NCB, located immediately adjacent to (and north of) the Qilian Shan and Qaidam block, thereby greatly reducing the aforementioned localization uncertainty of intracontinental convergence. But this study also raises some puzzling questions.

\section{Geology and paleomagnetic sampling}

The $5 \mathrm{~km}$ high Qilian Shan forms the NE edge of the Tibetan plateau. It connects kinematically to the large active Altyn Tagh left-lateral strike-slip fault to the West [20], [24] and [26]. In contrast, the $1.5 \mathrm{~km}$ high Hexi corridor of Gansu, just north of Qilian Shan, forms a topographic trough linking the Tarim Basin to the West with the Gobi Desert to the east. Tectonic activity in the Qilian Shan can be traced back at least to the Paleozoic (e.g. [39]), with several (not always well dated) phases of re-activation, for instance possibly between the Upper Triassic and Early Cretaceous (200-140 Ma, i.e. prior to deposition of our samples [40]) and more recently in the Eocene ( 40 Ma) and between the Miocene (20 Ma) and Present (fission track dating by Jolivet et al. [19]).

Paleomagnetic sampling was carried out near Yumen at the Early Cretaceous Xinminpo type section (star in Fig. 1a[41]). The $1000 \mathrm{~m}$ thick formation is divided into two parts, with underlying dark red and yellow-green colored fine grained sandstone intercalated with limestone and shale, and overlying brick red sandstone intercalated with conglomerates [41]. The Xinminpo Formation is underlain by the Sinian ( $700 \mathrm{Ma}$ ) Longshoushan Formation and is unconformably overlain by the Neogene Baiyanghe Formation. The angular unconformity is less than $10^{\circ}$. At the sampling site, the oldest Tertiary sediments overlying the Xinminpo Formation are Neogene $(<24 \mathrm{Ma})$, but at the basin scale these can be as old as Oligocene $(<38$ $\mathrm{Ma})$, giving a weak constraint on the age of folding. Fossils which were found in the Xinminpo type strata are listed in GBGMR [41]. Cyridea sinensis, Darwinula contracta (Ostracoda) and Cypridea latiovata are loosely constrained as Jurassic to Cretaceous. The species of Sphaerium (a lamellibranch) span the whole of the Cretaceous, whereas Darwinula contracta and Darwinula tubiformis were described in the lower part of the upper Dzunbain Formation in Mongolia and lie uniquely within the Lower Cretaceous. Thus the Xinminpo Formation is thought to be Lower Cretaceous.

Nine sites were sampled from the upper part of the Early Cretaceous Xinminpo Formation at Xiagouchun and Hongliuxia villages, north of Yumen city (Table 1). Eight to 10 cores were drilled, representing a minimum thickness of $10 \mathrm{~m}$ at each site, and oriented with both magnetic and, when possible, sun compasses. The average difference between the two sets of measurements is $0.5^{\circ} \pm 1.7(N=49)$, an almost negligible correction which was however applied to those cores without sun compass orientation. 
Table 1. Paleomagnetic results from Lower Cretaceous Xinminpo Formation (Yumen, Hexi Corridor, Gansu Province)

\begin{tabular}{llllllllll} 
Site & \multicolumn{1}{c}{$\begin{array}{l}\text { Coordinates } \\
\text { lat. }\left({ }^{\circ} \mathrm{N}\right) \text { long. }\left({ }^{\circ} \mathrm{E}\right)\end{array}$} & $\begin{array}{l}\text { Bedrike/dip } \\
\text { String }\end{array}$ & $n / N D_{\mathrm{g}}$ & $I_{\mathrm{g}}$ & $D_{\mathrm{s}}$ & $I_{\mathrm{s}}$ & $k$ & & $\alpha_{95}$ \\
YM01 39.9 & 97.9 & $102 / 9.5$ & $6 / 6$ & 20.4 & 45.4 & 22.2 & 54.7 & 42.5 & 10.4 \\
YM02 39.9 & 97.9 & $102 / 9.5$ & $6 / 7$ & 17.3 & 40.0 & 18.2 & 49.5 & 38.8 & 10.9 \\
YM03 39.9 & 97.9 & $102.5 / 9.5$ & $7 / 7$ & 22.9 & 50.8 & 25.7 & 60.1 & 69.7 & 7.4 \\
YM04 40.0 & 97.9 & $133.5 / 19.5$ & $7 / 7$ & 29.3 & 54.6 & 14.6 & 72.8 & 249.6 & 3.8 \\
YM05 39.9 & 97.9 & $75.5 / 14$ & $7 / 8$ & 11.1 & 48.0 & 21.1 & 60.2 & 61.1 & 7.8 \\
YM06 39.9 & 97.9 & $105.5 / 15$ & $7 / 7$ & 30.7 & 49.9 & 38.2 & 64.1 & 159.5 & 4.8 \\
YM10 40.0 & 97.3 & $80.5 / 41$ & $5 / 6$ & 4.4 & 31.4 & 26.4 & 69.5 & 20.6 & 17.3 \\
YM11 40.0 & 97.3 & $95.5 / 42.5$ & $7 / 8$ & 2.2 & 20.8 & 358.7 & 63.2 & 101.8 & 6.0 \\
YM12 40.0 & 97.3 & $95.5 / 42.5$ & $4 / 6$ & 5.7 & 15.4 & 6.0 & 57.8 & 580.1 & 3.8 \\
Mean & & & & 9 & 14.4 & 40.1 & & 25.3 & 10.4
\end{tabular}

$N$ and $n$ : number of samples measured and used to calculate mean; $D_{\mathrm{g}}, I_{\mathrm{g}}, D_{\mathrm{s}}, I_{\mathrm{s}}$ : declination and inclination in geographic and stratigraphic coordinates respectively; $k$ and $\alpha_{95}$ : Fisher statistical parameters.

\section{Laboratory analyses}

We first carried out experiments to determine the magnetic mineralogy of some representative samples. Isothermal remanent magnetization (IRM) experiments (using an IM30 pulse magnetizer) indicate both hard and soft coercivity magnetic minerals; saturation is not reached by $1000 \mathrm{mT}$ (Fig. 2a). A rapid increase of IRM up to about $200 \mathrm{mT}$ is sometimes observed. After removal of a (sometimes large) paramagnetic component, magnetic hysteretic curves show that the induced magnetic moment is saturated at about 200-300 mT (Fig. 2b). Thermal magnetic experiments (using a KLY3 kappabridge susceptibility meter coupled with a CS3 furnace) show either a sharp drop in magnetic susceptibility at about $580^{\circ} \mathrm{C}$, indicating magnetite as the main magnetic mineral, or a progressive decrease from 500 to $680^{\circ} \mathrm{C}$, indicative of hematite (Fig. 2c). In addition, sample 12-102 in Fig. 2c shows some evidence for a Hopkinson peak near $580^{\circ} \mathrm{C}$, indicative of single domain magnetite (e.g. [42]). No significant drop was observed at lower temperatures (Fig. 2c). 

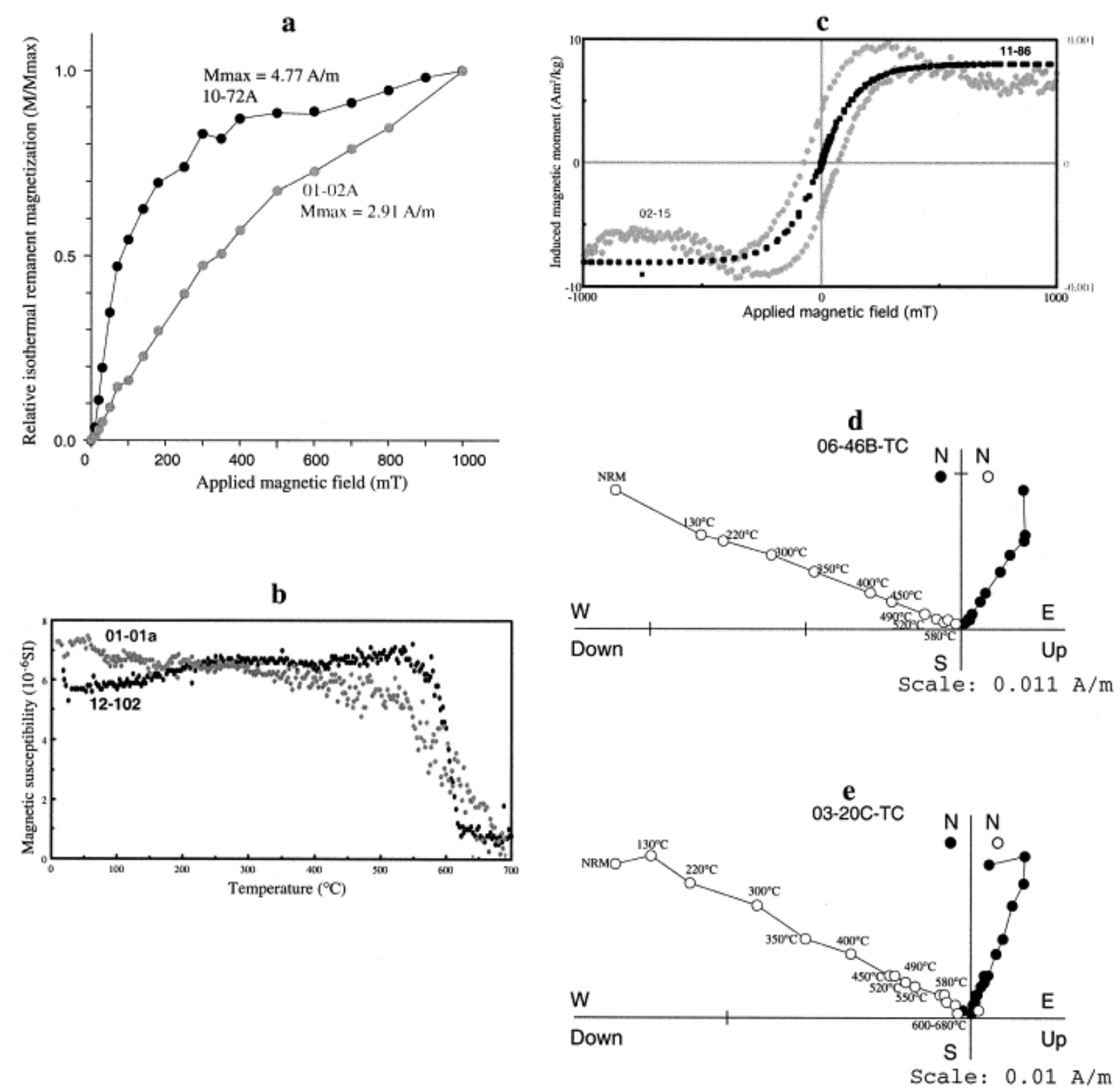

Fig. 2. Magnetic mineralogical studies and demagnetization curves. (a) IRM. (b) Magnetic hysteresis curves. (c) Thermomagnetic experiments. (d,e) Orthogonal vector plots (thermal demagnetizations).

Thermal demagnetization was conducted in a laboratory-built furnace in 12-16 progressive steps, with intervals of $20-150^{\circ} \mathrm{C}$. Magnetic remanence was measured with a JR5 spinner magnetometer. The magnetic susceptibility of each sample was measured after each heating step, and no significant variation was observed, indicating a probable lack of mineralogical transformation during heating. Two components were isolated from most samples (Fig. 2d,e). Lower unblocking temperatures (LT) were less than $200^{\circ} \mathrm{C}$, and higher temperatures (HT) went up to $580^{\circ} \mathrm{C}$ (Fig. $2 \mathrm{~d}$ ) and $680^{\circ} \mathrm{C}$ (Fig. $2 \mathrm{~d}$ ). Magnetic directions were isolated using principal component analysis [43]. The HT directions identified in all samples showed only one polarity, with downward inclination and northeastward declination. There are actually two (partly overlapping) higher temperature components carried respectively by magnetite (up to $580^{\circ} \mathrm{C}$ ) and hematite (beyond $580^{\circ} \mathrm{C}$ and up to $680^{\circ} \mathrm{C}$, but also below $580^{\circ} \mathrm{C}$ ), but both showed a consistent magnetic direction (Fig. $2 \mathrm{~d}$,e). Fisher statistics were used to compute site averages. The LTC $\left(D_{\mathrm{g}}=4.3^{\circ}, I_{\mathrm{g}}=53.4^{\circ} ; \alpha_{95}=4.9^{\circ}, N=9\right.$ sites $)$ is close to the present Earth's 
field direction $\left(D=1.3^{\circ}, I=56.7^{\circ}\right)$, with a negative fold test $\left(k_{\mathrm{s}} / k_{\mathrm{g}}=0.7\right)$. The high temperature component (HTC) yields a positive fold test at the $95 \%$ significance level [44] with $D_{\mathrm{s}}=18.9^{\circ}, I_{\mathrm{s}}=61.7^{\circ}$ $\left(\alpha_{95 \mathrm{~s}}=5.7^{\circ}, N=9 ; k_{\mathrm{s}} / k_{\mathrm{g}}=3.2\right.$; see Fig. 3a,b and Table 1$)$. The Watson and Enkin [45] test gives a maximum grouping of directions at $82 \%$ unfolding (with uncertainties ranging from 64 to $103 \%$ ), statistically indistinguishable from total unfolding. Hence the characteristic paleomagnetic direction was likely acquired prior to folding. Because consistent directions are carried by both magnetite and hematite, and because of the positive fold test, the magnetization is probably primary. The oldest sediments overlying the unconformity would appear to constrain the acquisition age to be older than Oligocene. The fact that only normal polarities are observed is consistent with deposition and magnetization within the Cretaceous Long Normal Superchron, hence with an age between 118 and 83 Ma. Because paleontological analysis of these rocks indicates that they are Early Cretaceous, the age range comes to $\sim 100-118 \mathrm{Ma}$, i.e. roughly the $110 \pm 10 \mathrm{Ma}$ span. The corresponding VGP is at $\lambda=75.5^{\circ} \mathrm{N}, \varphi=169.9^{\circ} \mathrm{E}\left(A_{95}=7.7^{\circ}\right)$.

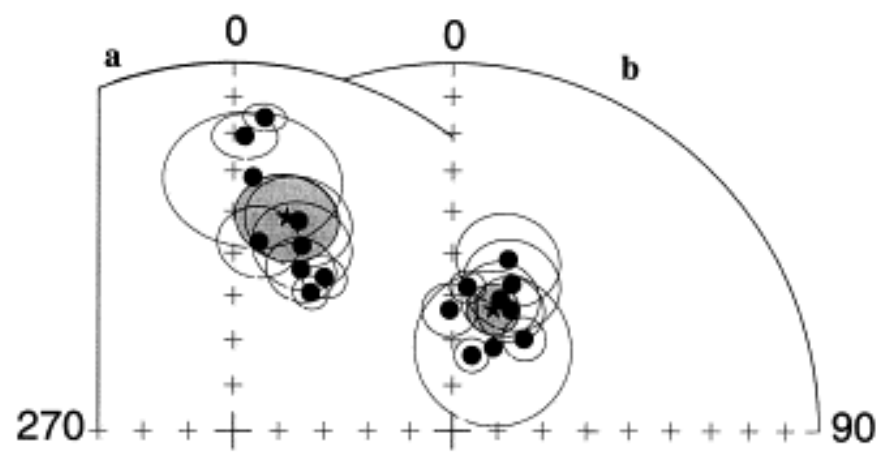

Fig. 3. Equal-area stereographic plot of site-mean directions before (a) and after (b) bedding corrections with their $95 \%$ confidence circle.

\section{Discussion}

Frost et al. ([27]; in which two of us participated) reported preliminary paleomagnetic results from the Hexi corridor, in which they combined data from three localities (Sunan, Lanzhou and Zhangye areas; see fig. 2b of Frost et al. [27]; these are respectively labelled A, B and C in Fig. 1a). Results from locality $\mathrm{C}$ were found to be noisy and were eventually discarded. Localities A and B yielded lower temperature and less stable HTC. To better isolate the HTC magnetic directions, the remagnetization great circle technique was applied to 14 out of 21 specimens. Actually, the 16 samples from Sunan area (A) were more dispersed after bedding correction ( $k$ decreasing from 75 to 56). Only five specimens from Lanzhou region (area B) were heated, and only up to $640^{\circ} \mathrm{C}$ : they could have been incompletely demagnetized. Even more important, from both geographic and tectonic points of view, the Sunan area is situated in the northeastern piedmont of the Qilian range, whereas the Lanzhou area lies on the western flank of the southeastern termination of the Qilian Mountains (Fig. 1). Major deep crustal left-lateral faults, most prominently the Haiyuan fault [46], cross this region and separate the Tibetan plateau from the NCB. Based on more numerous and higher quality data, Halim et al. [9] argued that the paleolatitude and paleodeclination of the Lanzhou-Xining Basin were more compatible with those from the Qaidam Basin than with the NCB in the Early Cretaceous. Therefore, the two areas studied by Frost et al. [27] probably belong to distinct tectonic units (Qaidam and the NCB) that have suffered differential deformation since 
the Cretaceous and should not be combined. Because of this tectonic problem, and because of the small quantity and lack of robustness of the preliminary data from Frost et al. [27], their results are superseded by those from the present study for the Sunan area (Hexi corridor) and of Halim et al. [9] for the Lanzhou (i.e. Qaidam) area.

Three studies are available for the Early Cretaceous of the NCB [3], [12] and [14]. These are listed in Table 2 and shown in Fig. 4a. The distance between the mean of the three NCB $\mathrm{K}_{1}$ poles and our Yumen pole is $11.2 \pm 10.9^{\circ}$, hence appears significantly different from zero at the $95 \%$ confidence level. However, the mean of the four studies (including Yumen) is at $80.1^{\circ} \mathrm{N}, 204.2^{\circ} \mathrm{E}\left(A_{95}=7.9^{\circ}\right)$ and comprises all four poles in its $95 \%$ cone of confidence (Fig. 4a). Moreover, three mean poles: (1) the Yang and Besse [7] pole for the Early Cretaceous of both the NCB and Mongolia (recalculated with a correction to Pruner's [47] pole for Mongolia), (2) the Early+Late Cretaceous pole of Gilder and Courtillot [5], and (3) a pole we calculate from seven Early+Late Cretaceous poles (Table 2), are all virtually identical with the new mean Early Cretaceous pole obtained above. We conclude that the Yumen site very likely belonged to the NCB, within paleomagnetic uncertainty, at least since the Cretaceous. This would make Yumen the westernmost location where paleomagnetic constraints representing the NCB have been obtained so far, lying closest to the Tibet-NCB (or QaidamNCB) boundary in the Qilian Shan. 
Table 2. Cretaceous paleomagnetic poles from the NCB, SCB, Qaidam and Tarim blocks, and Eurasian reference

$\begin{array}{llllllll}\text { Age } & \begin{array}{l}\text { Coordinates } \\ \text { lat. }\left(\mathrm{N}^{\circ}\right)\end{array} & \text { long. }\left(\mathrm{E}^{\circ}\right) & & \lambda_{\mathrm{p}} & \varphi_{\mathrm{p}} & A_{95} & \text { References and notes } \\ \text { NCB } & & & & & & \\ \mathrm{K}_{1} & 42.0 & 119.2 & 6 & 82.9 & 249.5 & 5.7 & {[3]} \\ \mathrm{K}_{1} & 35.0 & 108.0 & 10 & 75.8 & 208.7 & 7.5 & {[12]} \\ \mathrm{K}_{1} & 37.0 & 120.7 & 11 & 81.3 & 217.3 & 5.9 & {[14]} \\ \mathrm{K}_{1} & 39.9 & 97.7 & 9 & 75.5 & 169.9 & 7.7 & \text { This study } \\ \text { Mean }_{1} & \mathrm{NCB} & & 4 & 80.1204 .2 & 7.9 & \text { This study } \\ \mathrm{K}_{1-2} & 37.2 & 105.0 & 10 & 74.5 & 203.4 & 8.2 & {[62]} \\ \mathrm{K}_{1-2} & 31.6 & 116.0 & 10 & 74.5 & 201.0 & 4.7 & {[5]} \\ \mathrm{K}_{2} & 40.1 & 112.9 & 4 & 79.6 & 170.1 & 5.8 & {[11]} \\ \text { Mean } \mathrm{K}_{1-2} & \mathrm{NCB} & & 7 & 78.6 & 199.2 & 4.5 & \text { This study } \\ \text { Mean } \mathrm{K}_{1-2} & \text { NCB } & & 5 & 78.6202 .6 & 6.2 & {[5]} \\ \text { Mean } \mathrm{K}_{1} & \text { NCB (includes Mongolian data) } & 3 & 82.5 & 225.1 & 10.2 & \text { Recalculated by [7] }\end{array}$

\section{SCB}

\begin{tabular}{|c|c|c|c|c|}
\hline $\mathrm{K}_{1}$ & 29.7 & 120.3 & 7 & $77.1227 .65 .5 \quad[63]$ \\
\hline $\mathrm{K}_{1}$ & 22.2 & 114.2 & 12 & $78.2171 .910 .6[64]$ \\
\hline $\mathrm{K}_{1}{ }^{\mathrm{a}}$ & 30.0 & 102.9 & 23 & $77.9244 .53 .2 \quad[65]$ \\
\hline $\mathrm{K}_{1}{ }^{\mathrm{a}}$ & 25.9 & 101.7 & & $64.6199 .63 .3 \quad[66]$ \\
\hline $\mathrm{K}_{1}{ }^{\mathrm{a}}$ & 26.8 & 102.5 & 7 & $69.0204 .04 .3 \quad[67]$ \\
\hline $\mathrm{K}_{1}{ }^{\mathrm{a}}$ & 22.7 & 108.7 & 8 & $86.526 .4 \quad 6.8 \quad[68]$ \\
\hline $\mathrm{K}_{1}{ }^{\mathrm{a}}$ & 18.8 & 109.4 & 6 & $83.2143 .09 .8 \quad[69]$ \\
\hline $\mathrm{K}_{1}{ }^{\mathrm{a}}$ & 27.9 & 102.3 & 11 & $77.4196 .214 .5[70]$ \\
\hline Mean $\mathrm{K}_{1}$ & SCB & & 8 & 78.8202 .19 .9 This study \\
\hline $\mathrm{K}_{2}$ & 25.0 & 116.4 & 20 & $67.9186 .29 .2 \quad[71]$ \\
\hline $\mathrm{K}_{2}$ & 32.0 & 119.0 & 19 & $76.3172 .610 .3[49]$ \\
\hline $\mathrm{K}_{2}$ & 23.0 & 115.0 & 43 & $66.0221 .53 .4 \quad[72]$ \\
\hline $\mathrm{K}_{2}$ & 26.0 & 117.2 & 5 & $66.9221 .45 .4 \quad[73]$ \\
\hline $\mathrm{K}_{2}{ }^{\mathrm{a}}$ & 30.0 & 102.9 & 16 & $74.8250 .86 .6 \quad[65]$ \\
\hline $\mathrm{K}_{2}{ }^{\mathrm{a}}$ & 26.5 & 102.3 & 18 & $81.9220 .97 .1 \quad[67]$ \\
\hline $\mathrm{K}_{2}{ }^{\mathrm{a}}$ & 26.0 & 117.3 & 20 & $65.1207 .25 .0 \quad[68]$ \\
\hline $\mathrm{K}_{2}{ }^{\mathrm{a}}$ & 23.1 & 113.3 & 19 & $56.2211 .53 .9 \quad[68]$ \\
\hline $\mathrm{K}_{2}{ }^{\mathrm{a}}$ & 23.7 & 108.7 & 9 & $79.47 .1 \quad 10.0[68]$ \\
\hline $\mathrm{K}_{2}{ }^{\mathrm{a}}$ & 26.6 & 102.4 & 20 & $78.9186 .65 .5 \quad[70]$ \\
\hline Mean $\mathrm{K}_{2}$ & SCB & & 10 & 74.3211 .16 .2 This study \\
\hline Mean $\mathrm{K}_{1-2}$ & SCB & & 18 & 76.3207 .85 .2 This study \\
\hline
\end{tabular}

\section{Qaidam}




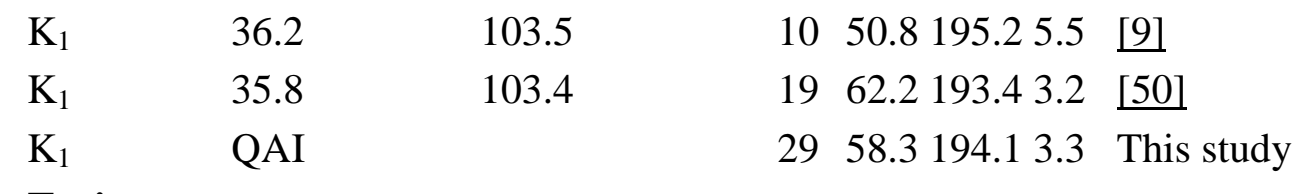

\section{Tarim}

$\begin{array}{llllllll}\mathrm{K}_{1} & 39.5 & 75.0 & 10 & 70.1 & 225.8 & 7.0 & {[8]} \\ \mathrm{K}_{1} & 41.8 & 82.0 & 6 & 64.6 & 208.9 & 9.0 & {[52]} \\ \mathrm{K}_{1} & \text { TAR } & & 16 & 67.0 & 214.1 & 6.0 & \text { This study }\end{array}$

\section{Eurasia}

$110 \pm 10 \mathrm{Ma}$ BC01

$1879.9181 .93 .9 \quad[48]$

$\lambda_{\mathrm{p}}, \varphi_{\mathrm{p}}$ and $A_{95}$ are pole latitude, longitude and radius of $95 \%$ cone of confidence.

$\mathrm{a}$

Poles suspected to have suffered local rotations.

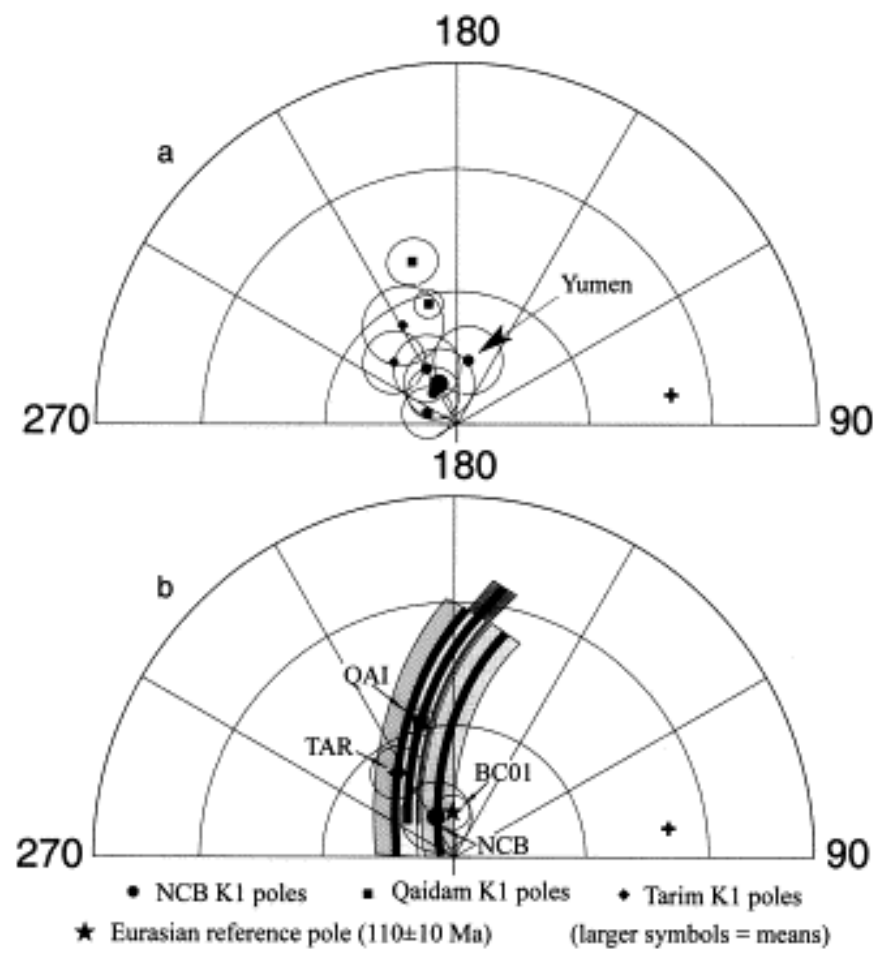

Fig. 4. (a) Equal-area stereographic plot of paleomagnetic poles from the NCB (smaller circles) and their mean (larger circle). The squares and diamonds are for individual poles from Qaidam [9] and [50] and Tarim [8] and [52] respectively. (b) Comparison of mean Cretaceous poles for the NCB (circle), Tarim (square), Qaidam (diamond) and stable Europe (star; 110 \pm 10 Ma synthetic pole for stable Europe from [48]). The Yumen site is indicated by a cross, together with small circles around it going through mean poles to indicate possible relative rotations about vertical axes.

Table 2 also lists available Cretaceous studies from the SCB. The Early Cretaceous mean pole for the SCB based on eight studies is indistinguishable from the mean of four NCB studies 
(including Yumen), or from the 110 \pm 10 Ma synthetic pole of Besse and Courtillot [48] for Eurasia, all three mean poles being within or on the joint intersection of their $95 \%$ confidence intervals. When all Early and Late Cretaceous data for the NCB (seven studies) and SCB (18 studies) are averaged (Table 2), the mean poles are indistinguishable (angular difference $3.2 \pm 6.9^{\circ}$ ). Altogether, it seems that the Cretaceous poles of the NCB, the SCB and Eurasia are compatible (although the distance between $\mathrm{K}_{1-2} \mathrm{NCB}$ and Eurasian reference poles is on the verge of significance at $6.4 \pm 6.5^{\circ}$ ), suggesting that these cratons have not undergone significant relative motion since, which further implies that the India-Asia collision has not had large (paleomagnetically measurable) consequences on the relative configuration of these large blocks. This reiterates a conclusion already reached by Kent et al. [49], Enkin et al. [4], Gilder and Courtillot [5], Cogné et al. [6] and Yang and Besse [7], although it is also clear that some deformation occurred in the Cretaceous within the Mongol-Okhotsk suture [9]. Indeed, note that, seen from Central Asia, the three Cretaceous poles for the SCB, the NCB and Siberia/Eurasia fall in sequence with no major rotational differences and a latitudinal progression compatible with little shortening at the SCB/NCB and NCB/Siberia suture zones. However, both estimates of shortening are on the order of $3 \pm 6^{\circ}$, hence not statistically resolvable. Two paleomagnetic studies of Early Cretaceous formations have recently been carried out in two separate localities of the Lanzhou-Xining Basin in the Qaidam [9] and [50]. The $95 \%$ confidence intervals of these two poles fail to intersect (Fig. 4a). However, the two studies share a number of characteristics: in both, the HTC is carried by magnetite and hematite, and positive fold and reversal tests are obtained. For the sake of the present discussion, the differences are small enough that averaging the 29 sites together provides a reasonable estimate of the mean Early Cretaceous Qaidam pole: the corresponding mean lies at $58.3^{\circ} \mathrm{N}, 194.1^{\circ} \mathrm{E}\left(A_{95}=3.3^{\circ}\right.$; Table 2 and Fig. $\left.4 b\right)$.

As seen in Fig. 4b, the Early Cretaceous NCB and Qaidam poles are different. This results in a significant paleolatitude difference $(\Delta \lambda)$ of $6.7 \pm 4.5^{\circ}$ and a large declination difference $(\Delta R)$ of $23.1 \pm 5.4^{\circ}$ at a reference site near Yumen $\left(39.9^{\circ} \mathrm{N}, 97.7^{\circ} \mathrm{E}\right)$ (uncertainties calculated following [51]). Corresponding values would be smaller (resp. larger) if the Yang et al. [50] (resp. [9]) results were used for Qaidam, which indicates that the Qaidam Basin has probably suffered heterogeneous deformation and one limited area might not be representative of the whole block [30]. The declination difference is interpreted as indicating an overall $23 \pm 5^{\circ}$ clockwise tectonic rotation of Qaidam with respect to Asia. The latitudinal discrepancy, taken to represent $740 \pm 500 \mathrm{~km}$ of north-south convergence between the NCB and Qaidam across the Qilian Shan and related ranges, is in any case in excess of $240 \mathrm{~km}$ at the $97.5 \%$ confidence level (with the $740 \mathrm{~km}$ value being rigorously the most probable based on the paleomagnetic data alone).

Before exploring the consequences of these results for the history of Tibet-NCB convergence, we need to take into account another important tectonic block, namely Tarim (Fig. 1a). Two Early Cretaceous studies are available for Tarim: Li et al. [52] on the northern margin (near $42^{\circ} \mathrm{N}, 82^{\circ} \mathrm{E}$ ) and Chen et al. [8] on the southern margin (near $40^{\circ} \mathrm{N}, 75^{\circ} \mathrm{E}$ ). The two poles are statistically similar (Fig. 4a) and their mean is at $67^{\circ} \mathrm{N}, 214.1^{\circ} \mathrm{E}\left(A_{95}=6.0^{\circ}\right)$. It is seen in Fig. $4 \mathrm{~b}$ that the Tarim and NCB poles are not compatible with one another (their $95 \%$ confidence intervals barely intersect). At the same reference in Yumen, the paleolatitude and rotational differences are respectively $9.6 \pm 6.0^{\circ}$ and $9.2 \pm 7.0^{\circ}$.

The corresponding differences for Qaidam versus Tarim are $\Delta \lambda=2.9^{\circ} \pm 5.5^{\circ}$ and $\Delta R=13.9 \pm 6.9^{\circ}$. This result does not come as a major surprise. Literally, it would imply insignificant latitudinal motion and a $14 \pm 7^{\circ}$ clockwise rotation of Qaidam with respect to Tarim since the 
Cretaceous. The latter result is similar to the significant clockwise rotation of $15 \pm 5^{\circ}$ already found by Chen et al. [30] to have taken place in the last $20 \mathrm{Ma}$ or so.

On the other hand, the Yumen+NCB pole produces puzzling implications. Although the large clockwise rotation of Qaidam with respect to the NCB is compatible with recent kinematics [53] and with major intracontinental convergence in the Qilian Shan, the paleolatitudinal results require further discussion. If we remove the probable $250 \mathrm{~km}$ of Cenozoic convergence, identical and kinematically linked to what is observed on the Altyn Tagh fault, we are left with an overall convergence of $490 \pm 500 \mathrm{~km}$. Clearly, this is not statistically significant, i.e. it cannot be ascertained at the $95 \%$ probability level to be distinct from zero. However, the mean value remains the one with maximum probability and we cannot discard the idea that a few hundred kilometers more of motion could have taken place in this $~ 200$ $\mathrm{km}$ wide orogenic range, larger than the values suggested by geological observation, or by the current width and height of the Qilian range.

A recent synthesis [26] on the formation of Tibet since the onset of the collision, 50-65 Ma ago [54] and [55], involves three major successive steps of growth and uplift of crustal thrust wedges, up to $500 \mathrm{~km}$ each in width. An Eocene, then an Oligo-Miocene, and finally a PlioQuaternary plateau are identified, built following oblique subduction of mantle lithosphere and extrusion along large sinistral faults. The most recent phase corresponds to the build-up of the Qaidam plateau, its extrusion along the Altyn Tagh fault (to the west) and Haiyuan and Qinling faults (to the east), and rise of the Qilian Shan. We must undo this major last phase of deformation to contemplate what Tibet may have looked like in the Miocene, with its northern boundary located along the Kunlun Shan and Kunlun fault. It should be emphasized (Fig. 1b, and [26], from which it is excerpted) that major intracontinental convergence, with subduction of continental lithosphere, must have occurred along the Jinsha, then Kunlun sutures, and may be starting along and under the Qilian suture. So one could conclude that paleomagnetic data indicate an earlier phase of convergence in the Qilian suture area. Recall that at least one Eocene tectonic phase is suggested by the data of Jolivet et al. [19].

But the tectonic analysis must be kinematically consistent, and all three blocks of Tarim, NCB and Qaidam must of course be considered together. And the major discrepancy comes from considering the pair of Tarim and NCB poles (Fig. 4). Tarim and the NCB had long been assumed to have formed the same tectonic unit because of lack of a clear suture between the two (but see [40]). Paleomagnetic data show that the two blocks could not have attained their present relative configuration before at least the Mesozoic [56]. Gilder and Courtillot [5] see final amalgamation of the NCB and the SCB at 159 $\pm 8 \mathrm{Ma}$. Therefore, poles from Tarim and the NCB younger than Jurassic would have been expected to be identical. But we see from Fig. 4 that the Tarim and NCB poles are not compatible and would seem to require $1000 \pm 800$ $\mathrm{km}$ motion, whereas there is no generally recognized Cenozoic tectonic boundary between the two.

To resolve this large amount of convergence, we can suggest at least three 'tectonic' interpretations and one 'sedimentary' counter-interpretation. First, we could propose that an as yet unobserved boundary between Tarim and the NCB occurs, maybe in the desertic corridor near $95-100^{\circ}$ longitude (as proposed for instance by [4]). This might extend as a NS trending strike-slip zone now obliterated beneath the eastern Kunlun and Qaidam thrusts. It could link in some way with the Mongol-Okhotsk and Altai-Sayan Tuva ranges and sutures. However, geological observations do not provide support for what should be a fairly conspicuous zone of large-scale Cenozoic deformation. A second hypothesis would imply a 
clockwise rotation of the Tarim block, with a hinge or pole of rotation not far from the eastern termination of Tarim. This is akin to the kinematic model of Avouac and Tapponnier [53], which has Tarim currently rotating clockwise with respect to Siberia in a clockwise sense at $0.65^{\circ} \mathrm{Ma}$ about a pole at $43.5^{\circ} \mathrm{N}, 95.7^{\circ} \mathrm{E}$, i.e. $500 \mathrm{~km}$ to the $\mathrm{NW}$ of Yumen (Fig. 1a). For an order of magnitude calculation, continued rotation for the last $20 \mathrm{Ma}$, i.e. at the time of main development of the NE Altyn Tagh and Qilian Shan, would result in a $13^{\circ}$ finite rotation, or a $250 \mathrm{~km}$ northward motion at the locations of Yingjisha $\left(39^{\circ} \mathrm{N}, 76^{\circ} \mathrm{E}\right.$ [8]) and Paicheng-Kuche $\left(42^{\circ} \mathrm{N}, 82-83^{\circ} \mathrm{E}\right.$ [52]): these Tarim (sensu stricto) sites are located respectively on the southern and northern margins of the block, 1700 and $1500 \mathrm{~km}$ west of our Yumen site. This would have the advantage of corresponding to the documented recent motion of the blocks, and of avoiding intense deformation (again not observed) at the junction between Tarim and the NCB. A third hypothesis is that the Tarim data, which are still few, may not everywhere represent the stable Tarim block. Again, the southern margin data near Yingjisha are $1700 \mathrm{~km}$ west of our Yumen site, and there are no other data available on the Tarim margin in between. There have been suggestions [57] and [58] that there was an older phase of motion on the Altyn Tagh fault and on major parallel strands to the north (Checheng fault). Some Cenozoic motion could have taken place between the southern Tarim site and some thrust system located north of Yingjisha, up to the Maza Tagh in Central Tarim. Note that all three mechanisms could contribute some amount to the total larger displacement, but this is not testable in the current state of our knowledge and data.

An alternative to a tectonic hypothesis would be to invoke some form of shallowing of the paleomagnetic inclinations (by about $10^{\circ}$ ) of all Lower Cretaceous sediments in the Tarim and Qaidam, but not those in North China or at Yumen. Inclination shallowing has been uncovered in many paleomagnetic studies of Cenozoic red beds in Asia [6], [28], [34] and [38]. Interpretations other than tectonic include non-dipole field geometry [36], errors in the reference APWP for Siberia [6], errors in age determination of the largely nonfossiliferous red beds, or inclination shallowing due to sedimentary or rock magnetic problems at the time of acquisition of magnetization [28] and [37]. Besse and Courtillot [48] and [59] find no evidence for significant long-standing non-dipole field components other than a small axial quadrupole less than $5 \%$ of the axial dipole in the global data base.

A critical test could come from vindicating the paleomagnetic characteristic remanent magnetization (ChRM) determined from red beds with observations of ChRM from coeval lavas. This is unfortunately a difficult test, due to the dearth of adequate volcanic outcrops in Central Asia. Two such tests have recently become available. The first is from Paleogene basalts (estimated at $50 \pm 15 \mathrm{Ma}$ ) from the Kyrgyz Tien Shan near $41^{\circ} \mathrm{N}, 76^{\circ} \mathrm{E}$, studied by Bazhenov and Mikolaichuk [38]. These yield an inclination difference of $7.9 \pm 4.8^{\circ}$ with respect to those predicted by the Besse and Courtillot master curve at $50 \mathrm{Ma}$, and virtually zero if the age were $60 \mathrm{Ma}$, which is within the estimated age uncertainty. In any case this is $10-20^{\circ}$ steeper than most observed inclinations in Cenozoic red beds from Central Asia, confirming the occurrence of significant inclination shallowing in these red beds (see also [28]). Should these results be confirmed, it seems that the hypothesis that the Siberian APWP is not well modelled by the Eurasian APWP due to internal deformation [6] is not required by the data.

The effect is far smaller, if not negligible in older Mesozoic red beds [38]. Zhao et al. [60], and X. Zhao (personal communication, 2002) have measured $\mathrm{K}-\mathrm{Ar}$ dated Cretaceous basalt samples from the Trans-Baykal region $\left(50-52^{\circ} \mathrm{N}, 105-111^{\circ} \mathrm{E}\right)$, which yield positive fold and reversal tests and are not statistically different from the 95-130 Ma reference poles of Besse 
and Courtillot [59] in terms of latitude. Therefore, the Eurasian based reference APWP is apparently appropriate for Cretaceous Siberia, and there is no reason to revise the interpretations based on data of this age (e.g. [6] and [8]), contrary to what is suggested by Bazhenov and Mikolaichuk [38]. There is therefore no reason to suspect that Mesozoic paleomagnetic data are affected by large inclination shallowing, contrary to what is observed in Cenozoic data. With this in mind, we have analyzed the anisotropy of magnetic susceptibility (AMS) of 60 samples from our Yumen collection. The mean anisotropy is in the order of $1.5 \%$ or less, and the mean principal $\left(\mathrm{k}_{1}\right)$ axes have a westward declination and a shallow inclination of about $11^{\circ}$ to the NNE, which, if interpreted as indicating that the sediments were not initially horizontal, would lead to an even larger discrepancy in inclinations, hence paleolatitudes. We therefore believe that the AMS of our samples is a primary, sedimentary one which gives no reason to invoke inclination shallowing. It would of course be interesting to further conduct experiments and corrections as outlined for instance by Kodama [61], and we intend to undertake these rather time-consuming experiments.

\section{Conclusion}

We have reported new paleomagnetic results from nine sites of the Early Cretaceous Xinminpo Formation collected near Yumen in the Hexi Corridor of Northwestern China. A normal polarity, high temperature characteristic magnetic component is isolated and passes a fold test: we argue that this is a primary magnetization which can be dated at 100-118 Ma. The corresponding direction is slightly steeper than, but consistent with results from three other studies from the NCB. We conclude that, within paleomagnetic uncertainty, Yumen was part of the NCB as early as the beginning of the Cretaceous, and that the Hexi Corridor formed its westernmost extension. A review of published poles confirms previous views that the South and North China (plus Mongolia) blocks and the Siberian craton have not undergone very significant internal deformation since the Cretaceous, and therefore have not been very significantly modified by the India-Asia collision. It should be once more recalled that the still large uncertainties that pertain to these paleomagnetic results allow for tectonically significant latitudinal motions on the order of a couple of hundred kilometers or even more, for instance in the SCB/NCB and NCB/Siberia (Mongol-Okhotsk) suture zones.

When the NCB results are compared to the two studies available from the Qaidam block, i.e. the northeasternmost component of the Tibetan plateau (sensu lato), a major discrepancy is observed between the two poles. One might worry that some of the results are affected by inclination shallowing, as is observed in many Cenozoic red bed studies from Central Asia. Recent (but still partly unpublished and few in number) paleomagnetic studies of coeval lavas seem to confirm the inclination shallowing of Cenozoic rocks, and also to confirm the validity of the Eurasian reference APWP when it is considered applicable to the Siberian craton, both in the Paleogene and in the Cretaceous. But there is no evidence that most or all of Asian Mesozoic red beds suffer the same inclination shallowing as the Cenozoic ones. In any case no inclination shallowing is suggested (or needed) to account for our Yumen results (which on the contrary tend to be a bit steep), and measurements of AMS seem to confirm a flat sedimentary fabric. An interpretation in terms of inclination shallowing would actually require that all results from Tarim and Qaidam suffer from this effect, yet none of those from North China or Yumen, which would seem a strange coincidence. Since non-dipole field hypotheses seem equally untenable, we are left with tectonic interpretations, some of which may seem puzzling and require further testing by field observations. 
The fact that our Yumen results, and those from the NCB, require a significant $\left(\sim 20^{\circ}\right)$ clockwise rotation of Qaidam with respect to the $\mathrm{NCB}$ (and $\sim 15^{\circ}$ with respect to Tarim) confirms previous results and does not come as a surprise. The significant north-south convergence between the NCB and Qaidam in the Qilian Shan is not a surprise either, although its value, even after correction for up to $250 \mathrm{~km}$ of latitudinal motion due to large strike-slip in the Altyn Tagh fault, is quite large at $490 \pm 500 \mathrm{~km}$ (if very uncertain). A larger or earlier phase of convergence in the Qilian Shan is therefore suggested by paleomagnetism, which could correspond to Eocene fission track ages recently reported from there. But the most puzzling results implied by the combined Yumen and NCB results is a large latitudinal motion of $1000 \pm 800 \mathrm{~km}$ between Tarim and the NCB: these two blocks had been generally considered as forming a single stable entity since about $160 \mathrm{Ma}$. Three tectonic hypotheses can be made to interpret these results: (1) the existence of an as yet unobserved major NS trending strike-slip boundary between Tarim and the NCB near $95-100^{\circ}$ longitude in the desertic corridor between the two blocks; (2) the existence of major NS motion in the Maza Tagh, north of our southernmost western Tarim margin sites, which would therefore not have been part of stable Tarim since their deposition; and (3) clockwise rotation of the Tarim plate with respect to the NCB about a pole located near its eastern termination. Twenty million years of persistent rotation about the pole found by Avouac and Tapponnier [53] to describe current block kinematics at the current rate would lead to $13^{\circ}$ of rotation and $250 \mathrm{~km}$ of NS motion at the western sites sampled in Tarim for paleomagnetism. In any case, the Yumen results narrow down the location of large, previously documented NS motion between Tibet and Siberia which must have taken place in the Qilian Shan. In the last $20 \mathrm{Ma}$ of the collision, the Qilian Shan has become the northern margin at which an increasing fraction of the IndiaAsia collision is absorbed.

\section{Acknowledgments}

We gratefully acknowledge financial support from the Natural Sciences Foundation of China (NSFC, No. 49525406, 40074017) and the Institut National des Sciences de l'Univers. We also thank Drs. Shi and Bridonneau for their help in the field and laboratory. V.C. wishes to thank the California Institute of Technology for a distinguished Moore fellowship and members of its Division of Geological and Planetary Sciences for welcome and support while his contribution to this paper was being written. M. Allen and an anonymous reviewer provided helpful suggestions. IPGP contribution 1820.[AC]

\section{References}

Y. Chen, V. Courtillot, J.-P. Cogné, J. Besse, Z. Yang, R. Enkin

The configuration of Asia prior to the collision of India: Cretaceous paleomagnetic constraints

J. Geophys. Res., 98 (1993), pp. 21927-21941

X. Zhao, R. Coe

Paleomagnetic constraints on the collision and rotation of North and South China

Nature, 327 (1987), pp. 141-144

X. Zhao, R.S. Coe, Y. Zhou, H. Wu, J. Wang

New paleomagnetic results from northern China collision and suturing with

Siberia and Kazakhstan

Tectonophysics, 181 (1990), pp. 43-81 
R. Enkin, Z. Yang, Y. Chen, V. Courtillot

Paleomagnetic constraints on the geodynamic history of the major blocks of China from the Permian to the Present

J. Geophys. Res., 97 (1992), pp. 13953-13989

S. Gilder, V. Courtillot

Timing of the North-South China collision from new middle to late Mesozoic paleomagnetic data from the North China Block

J. Geophys. Res., 102 (1997), pp. 17713-17727

J.-P. Cogné, N. Halim, Y. Chen, V. Courtillot

Resolving the problem of shallow magnetization of Tertiary age in Asia: insights from paleomagnetic data from the Qiangtang, Kunlun and Qaidam blocks (Tibet, China), and a new hypothesis

J. Geophys. Res., 104 (1999), pp. 17715-17734

Z. Yang, J. Besse

New Mesozoic apparent polar wander path for South China: tectonic consequence J. Geophys. Res., 106 (2001), pp. 8493-8520

Y. Chen, J.-P. Cogné, V. Courtillot

New Cretaceous paleomagnetic poles from the Tarim basin, northwestern China Earth Planet. Sci. Lett., 114 (1992), pp. 17-38

N. Halim, J.-P. Cogné, Y. Chen, R. Atesiei, J. Besse, V. Courtillot, S. Gilder, J. Marcoux, R. Zhao

New Cretaceous and Early Tertiary paleomagnetic results from Xining-Lanzhou basin, Kunlun and Qiangtang blocks, China: implication on the geodynamic evolution of Asia

J. Geophys. Res., 103 (1998), pp. 21025-21045

Y. Chen, J.-P. Cogné, V. Courtillot, P. Tapponnier, X. Zhu

Cretaceous paleomagnetic results from western Tibet and tectonic implications

J. Geophys. Res., 98 (1993), pp. 17981-17999

Z. Zheng, M. Kono, H. Tsunakawa, G. Kimura, Q. Wei, X. Zhu, T. Hao

The apparent polar wander path for the North China Block since the Jurassic

Geophys. J. Int., 104 (1991), pp. 29-40

X. Ma, Z. Yang, L. Xing

The Lower Cretaceous reference pole from the North China and its tectonic implications

Geophys. J. Int., 115 (1993), pp. 323-331

S. Gilder, J. Gille, R. Coe, X. Zhao, H. Liu, G. Wang, K. Yuan, W. Liu, G. Kuang, H. Wu $\mathrm{H}$, Isotopic and paleomagnetic constraints on the Mesozoic tectonic evolution of south China

J. Geophys. Res., 101 (1996), pp. 16137-16154

S. Gilder, P. Leloup, V. Courtillot, Y. Chen, R. Coe, X. Zhao, W. Xiao, N. Halim, J.-P. Cogné, R. Zhu 
Tectonic evolution of the Tancheng-Lujiang (Tan-Lu) fault via Middle Triassic to Early Cenozoic paleomagnetic data

J. Geophys. Res., 104 (1999), pp. 15365-15390

S. Gu, H. Di, Mechanism of formation of the Qaidam basin and its control on petroleum, in: X. Zhu (Ed.), Chinese Sedimentary Basins, Elsevier, Amsterdam, 1989, pp. 45-51.

Z. Zhang, High pressure-low temperature metamorphism in North Qilian, China (in Chinese with English abstract), in: G. Cui, B. Shi (Eds.), The Exploration for Geological Science of China, Publishing House of Beijing University, Beijing, 1989, pp. 273-295.

F. Métivier, Y. Gaudmer, P. Tapponnier, B. Meyer

Northeastward growth of the Tibet Plateau deduced from balanced reconstruction of two depositional areas the Qaidam and Hexi basins, China

Tectonics, 17 (1998), pp. 823-842

Yin, P. Kapp, M. Murphy, C. Manning, M. Harrison, M. Grove

Significant late Neogene east-west extension in northern Tibet

Geology, 27 (1999), pp. 787-790

M. Jolivet, M. Brunel, J. Malavieille, D. Seward, J. Yang, Z. Xu, P. Tapponnier, Tectonic evolution of Northern Tibet: Fission track constraints, in: International Symposium on Geoscience of the Northern Qinghai-Tibet Plateau, 2000.

G. Peltzer, P. Tapponnier, R. Armijo

Magnitude of late Quaternary left-lateral displacements along the northern edge of Tibet

Science, 246 (1989), pp. 1285-1289

Mériaux, P. Tapponnier, F. Reyerson, J. Van der Woerd, G. King, R. Finke, M. Caffe, Application of cosmogenics 10B and 36Al dating to neotectonics of the Altyn Tagh in Central Asia (Gansu, China), AGU Fall Meeting, 1997.

$\mathrm{H}$. Wu

Mineralogical and polytypic characteristics of phengite and inspiration for K-Ar ages in Northern Qilian Mountains, China

Bull. Xian Inst. Geol. Miner. Resour., 15 (1987), pp. 22-46

H. Wu, F. Feng, S. Song

Metamorphism and deformation of blueschist belts and their tectonic implications, North Qilian mountains, China

J. Metamorph. Geol., 11 (1993), pp. 523-536

B. Meyer, P. Tapponnier, L. Bourjot, F. Métivier, Y. Gaudmer, G. Peltzez, S. Gou, Z. Chen

Crustal thickening in Gansu-Qinghai, lithospheric mantle subduction, and oblique, strike-slip controlled growth of the Tibet plateau

Geophys. J. Int., 135 (1998), pp. 1-47

J. Van der Woerd, Couplage, cinématique entre décrochements et chevauchements actifs dans le Nord du Tibet. Croissance du plateau tibétain, Ph.D. Thesis, 1998, pp. 411. 
P. Tapponnier, Z. Xu, F. Roger, B. Meyer, N. Arnaud, G. Wittlinger, J. Yang Oblique stepwise rise and growth of the Tibet Plateau

Science, 294 (2001), pp. 1671-1677

G. Frost, R. Coe, Z. Meng, Z. Peng, Y. Chen, V. Courtillot, G. Peltzer, P. Tapponnier, J.Ph. Avouac

Preliminary Early Cretaceous paleomagnetic results from Gansu Corridor, China Earth Planet. Sci. Lett., 129 (1995), pp. 217-232

S. Gilder, Y. Chen, S. Sen

Oligo-Miocene magnetostratigraphy and environmental magnetism of the Xishuigou section, Subei (Gansu Province, western China): Further implication on the shallow inclination of central Asia

J. Geophys. Res., 106 (2001), pp. 30505-30521

G. Dupont-Nivet, Z. Gou, R. Butler, C. Jia

Paleomagnetism of Miocene rocks from the Maza Tagh in the Central Tarim basin: Evidence for local deformation or regional vertical-axis rotation?

Earth Planet. Sci. Lett., 199 (2002), pp. 473-482

Y. Chen, S. Gilder, N. Halim, J.-P. Cogné, V. Courtillot, New Mesozoic and Cenozoic paleomagnetic data help constrain the age of motion on the Altyn Tagh fault and rotation of the Qaidam basin, Tectonics, in press (2002).

S. Gilder, X. Zhao, R. Coe, Z. Meng, V. Courtillot, J. Besse

Paleomagnetism, tectonics and geology of the southern Tarim basin, northwestern China

J. Geophys. Res., 101 (1996), pp. 22015-22031

J. Thomas, H. Perroud, P. Cobbold, M. Bazhenov, V. Burtman, A. Chauvin, E.

Sadybokasov

A paleomagnetic study of Tertiary formations from the Kirghiz Tien Shan and its tectonic implications

J. Geophys. Res., 101 (1993), pp. 22015-22031

X. Zhao, R. Coe, Y. Zhou

Tertiary paleomagnetism of North and South China and a reappraisal of late Mesozoic paleomagnetic data from Eurasia: implication for the Cenozoic tectonic history of Asia

Tectonics, 235 (1994), pp. 181-203

Chauvin, H. Perroud, P. Cobbold

Anomalous low paleomagnetic inclinaisons from Oligocene-lower Miocene red beds of the south-west Tien Shan, central Asia

Geophys. J. Int., 126 (1996), pp. 303-313

N. Halim, V. Kravchinsky, S. Gilder, J.-P. Cogné, M. Alexyutin, V. Courtillot, Y. Chen A paleomagnetic study from Mongol-Okhotsk region: rotated Early Cretaceous volcanics and remagnetized sediments

Earth Planet. Sci. Lett., 159 (1996), pp. 133-145 
M. Westphal

Did a large departure from the geocentric axial dipole occur during the Eocene?

Evidence from the magnetic polar wander path of Eurasia

Earth Planet. Sci. Lett., 117 (1993), pp. 15-28

K. Kodama, X. Tan

Central Asia inclination anomalies: possible inclination shallowing in red beds

EOS Trans. AGU, 78 (Fall Meeting Suppl.) (1997), p. 174

M. Bazhenov, A. Mikolaichuk

Paleomagnetism of Paleogene basalts from the Tien Shan, Kyrgyzstan: rigid

Eurasia and dipole geomagnetic field

Earth Planet. Sci. Lett., 195 (2002), pp. 155-166

C. Xiao, Y. Gao

Re-exposition on plate tectonics of the Qinghai-Xizhang Plateau

Bull. Chin. Acad. Geol. Sci., 4 (1986), pp. 7-20

S. Vincent, M. Allen

Evolution of the Minle and Chaoshui basins, China: Implications for Mesozoic strike-slip basin formation in Central Asia

Geol. Soc. Am. Bull., 111 (1999), pp. 725-742

Gansu Bureau of Geology and Mineral Resources, Geological map of 1/200,000, 1974.

D. Dunlop, O. Ozdemir, Rock Magnetism, Cambridge University Press, Cambridge, 1997, $576 \mathrm{pp}$.

J. Kirschvink

The least square line and the analysis of paleomagnetic data

Geophys. J. R. Astron. Soc., 62 (1980), pp. 699-718

M. McElhinny

Statistical significance of the fold test in paleomagnetism

Geophys. J. R. Astron. Soc., 8 (1964), pp. 338-340

G. Walson, R. Enkin

The fold test in paleomagnetism as a parameter estimation problem

Geophys. Res. Lett., 20 (1993), pp. 2135-2137

Y. Gaudmer, P. Tapponnier, B. Meyer, G. Peltzer, S. Guo, Z. Chen, H. Dai, I. Cifuentes Partitioning of crustal slip between linked, active faults in the eastern Qilain Shan, and evidence for a major seismic gap, the 'Tienzu gap', on the western Hayuan fault, Gansu (China)

Geophys. J. Int., 120 (1995), pp. 599-645 
P. Pruner

Paleomagnetism and paleogeography of Mongolia from the Carboniferous to

Cretaceous - final report

Phys. Earth Planet. Inter., 70 (1992), pp. 169-177

J. Besse, V. Courtillot, Apparent and true polar wander and the geometry of the geomagnetic field in the last 200 million years, J. Geophys. Res., in press (2002)

D. Kent, X. Zeng, X. Zhang, N. Opdyke

Widespread late Mesozoic to recent remagnetization of Paleozoic and Lower Triassic sedimentary rocks from South China

Tectonophysics, 139 (1987), pp. 133-143

T. Yang, Z. Yang, Z. Sun, A. Li

New Early Cretaceous paleomagnetic results from the Qilian orogenic belt and its tectonic implications

Sci. China, 44 (2001), pp. 568-576

H. Demarest

Error analysis of the determination of tectonic rotation from paleomagnetic data

J. Geophys. Res., 88 (1983), pp. 4321-4328

Y. Li, Z. Zhang, M. McWilliams, R. Sharps, Y. Zhai, Y.A. Li, Q. Li, A. Cox

Mesozoic paleomagntic results of the Tarim craton: Tertiary relative motion between China and Siberia?

Geophys. Res. Lett., 15 (1988), pp. 217-220

J.-P. Avouac, P. Tapponnier

Kinematic model of active deformation in Central Asia

Geophys. Res. Lett., 20 (1993), pp. 895-898

P. Patriat, J. Achache

India-Eurasia collision chronology has implications for crustal shortening and driving mechanism of plates

Nature, 311 (1984), pp. 615-621

J. Jaeger, V. Courtillot, P. Tapponnier

A paleontological view on the ages of the deccan traps, of the Cretaceous-Tertiary boundary and of the India-Asia collision

Geology, 17 (1989), pp. 316-319

P. McFadden, M. McElhinny

The combined analysis of remagnetization circles and direct observations in paleomagnetism

Earth Planet. Sci. Lett., 87 (1988), pp. 152-160

Yin, M. Harrison

Geologic evolution of the Himalayan-Tibetan orogen

Annu. Rev. Earth Planet. Sci., 28 (2000), pp. 211-280 
E. Cowgill, A. Yin, X.F. Wang, Q. Zhang

Late Cenozoic left-slip movement along the Northern Altyn Tagh Fault and its possible development as the northern boundary of a transpressional strike-slip duplex

Geology, 28 (2000), pp. 255-258

J. Besse, V. Courtillot

Revised and synthetic polar wander paths of the African, Eurasian, North

American and Indian plates, and true polar wander since $200 \mathrm{Ma}$

J. Geophys. Res., 96 (1991), pp. 4029-4050

X. Zhao, R. Coe, D. Metelkin, I. Gordienko, J. Lyons, V. Klimuk, A. Petroutchik, A. Davydov, E. Hromova, L. Novokrechennih, Preliminary paleomagnetic results from Cretaceous basalts of the Trans-Baikal region, Southeastern Siberia, EOS Trans. AGU 82, Fall Meeting Suppl. (2001) Abstract GP11A-091.

K. Kodama

A successful rock magnetic technique for correcting paleomagnetic inclination shallowing: Case study of the Nacimiento Formation, New Mexico

J. Geophys. Res., 102 (1997), pp. 5193-5205

H. Wu, L. Zhou, Z. Zhao, Z. Yang, Y. Chen

Paleomagnetic results of the late Paleozoic and Mesozoic from the Alashan area of the northwestern China Block

Sci. Geol. Sin., 2 (1993), pp. 19-46

J. Lin, The Apparent Polar Wander Paths for the North and South China Blocks, Ph.D. Thesis, University of California, Santa Barbara, CA, 1985, 248 pp.

L. Chan

Paleomagnetism of Late Mesozoic granitic intrusions in Hongkong: Implications for upper Cretaceous reference pole of south China

J. Geophys. Res., 96 (1991), pp. 327-335

R. Enkin, V. Courtillot, L. Xing, Z. Zhuang, J. Zhang

The stationary Cretaceous paleomagnetic pole of Sichuan (South China Block)

Tectonics, 10 (1991), pp. 547-559

Y. Otofuji, Y. Liu, M. Yokoyama, M. Tamia

Tectonic deformation of the southwestern part of the Yangtze craton inferred from paleomagnetism

Earth Planet. Sci. Lett., 156 (1998), pp. 47-60

K. Huang, N. Opdyke

Paleomagnetism of Cretaceous to lower Tertiary rocks from southwestern Sichuan, a revisit

Earth Planet. Sci. Lett., 112 (1992), pp. 29-40

S. Gilder, R. Coe, H. Wu, X. Kuang, X. Zhao, Q. Wu, Z. Tang

Creteceous and Tertiary paleomagnetic results from southeast China and their tectonic implications

Earth Planet. Sci. Lett., 117 (1993), pp. 637-652 
Z. Li, I. Metcalfe, X. Wang

Vertical-axis bock rotations in southwestern China since the Cretaceous: New paleomagnetic results from Hainan Island

Geophys. Res. Lett., 22 (1995), pp. 3071-3074

Z. Zhu, T. Hao, H. Zhao

Paleomagnetic study on the tectonic motion of the Pan-Xi block and adjacent area during Yinzhi-Yanshan period

Acta Geosci. Sin., 31 (1988), pp. 420-431

L. Hu, P. Li, X. Ma

A magnetostratigraphic study of Cretaceous red beds from Shanghang, western Fujian (in Chinese)

Geol. Fujian, 1 (1990), pp. 33-42

V. Hsu

Paleomagnetic results from one of the red basins in south China (Abstract)

EOS Trans. AGU, 68 (1987), p. 295

Y. Zhai, M. Seguin, Y. Zhou, J. Deng, Y. Zheng

New paleoamgnetic data from the Huanan block, China and Cretaceous tectonics in eastern China

Phys. Earth Planet. Inter., 73 (1993), pp. 163-188 